Article

\title{
Financing Indian Urban Rail through Land Development: Case Studies and Implications for the Accelerated Reduction in Oil Associated with $1.5^{\circ} \mathrm{C}$
}

\author{
Rohit Sharma \\ Curtin University Sustainability Policy Institute (CUSP), Curtin University, Perth, WA 6845, Australia; \\ E-Mail: rohitsharma16@gmail.com
}

Submitted: 12 September 2017 | Accepted: 19 March 2018 | Published: 24 April 2018

\begin{abstract}
Urban travel demand and oil dependence need dramatic change to achieve the $1.5^{\circ} \mathrm{C}$ degree target especially with the electrification of all land-based passenger transport and the decarbonizing of electric power. In this article we investigate the transition of 'oil-based automobile dependence' to 'urban rail plus renewable energy' to cater for transport demand in Indian cities. India is perceived to be a key driver of global oil demand in coming decades due to the potential increase in car use driven by a fast growing national average income. However, it is possible that India could surprise the world by aggressively pursuing an electrified transit agenda within and between cities and associated supporting local transport with electric vehicles, together with renewable power to fuel this transport. The changes will require two innovations that this article focuses on. First, innovative financing of urban and intercity rail through land-based finances as funding and financing of such projects has been a global challenge. Second, enabling Indian cities to rapidly adopt solar energy for all its electrified transport systems over oil plus car dependence. The article suggests that Indian cities may contribute substantially to the $1.5^{\circ} \mathrm{C}$ agenda as both policies appear to be working.
\end{abstract}

\section{Keywords}

Keywords: $1.5^{\circ} \mathrm{C}$ agenda; cities; climate change; India; renewables; substantially; urban rail; urban travel

\section{Issue}

This article is part of the issue "Urban Planning to Enable a $1.5^{\circ} \mathrm{C}$ Scenario", edited by Peter Newman (Curtin University, Australia), Aromar Revi (Indian Institute for Human Settlements, India) and Amir Bazaz (Indian Institute for Human Settlements, India).

(C) 2018 by the author; licensee Cogitatio (Lisbon, Portugal). This article is licensed under a Creative Commons Attribution 4.0 International License (CC BY).

\section{Introduction}

Urban travel is the largest source of global transport related greenhouse emissions as well as associated issues such as air pollution. This is due to the urban travel being oil based and automobile dependent (Rode et al., 2014; Van Audenhove, Korniichuk, Dauby, \& Pourbaix, 2014). The Intergovernmental Panel on Climate Change, chapter on Transportation (Sims et al., 2014), notes that reduction in transport sector emissions is critical to achieve the future climate change goal such as the $1.5^{\circ} \mathrm{C}$ target suggested as the preferable limit to be addressed under the Paris Agreement. Electrification of all land-based passenger transport and the decarbonizing of electric power will be required to help achieve the $1.5^{\circ} \mathrm{C}$ target; this has been clearly stated as the necessary and fundamental change needed in all urban systems and has been agreed to by the nations of the world in the Paris Agreement. This article will try to show urban rail can play a significant part in this transition due to its ability to replace car use and its ability to create new funding opportunities through rail-oriented land development due to land value uplift.

Urban rail has shown its potential to simultaneously electrify transport and help reduce the occurrence of automobile dependence. Urban rail can also help increase economic development in cities as urban rail facilitates the creation of dense urban centres with walking and transit urban fabric that are known to help with new economy jobs and other social, economic and en- 
vironmental outcomes (Matan \& Newman, 2016; Newman, Kosonen, \& Kenworthy, 2016). One example from Glaeser and Xiong (2017) is of the Chicago stockyard where people and businesses have clustered around the associated rail stations. Such clusters attract additional business and lead to innovation due to the proximity of people and access to a large labour resource (Glaeser \& Xiong, 2017). Knowledge economy jobs are particularly attracted to such transit-oriented centres of activity (Newman \& Kenworthy, 2015; Yigitcanlar, 2010). Also, the energy intensity of rail transport is only about $15 \%$ of that of traditional cars, $50 \%$ of electric vehicles and $50 \%$ of buses (Lu, 2015). The major difference in the climate change debate is that urban rail is already mostly electric and therefore can be based quickly on renewable power. Thus, infrastructure investments that encourage rail may therefore lead to significant emission reductions in cities (Hoen et al., 2017).

If urban planning is to help with the $1.5^{\circ} \mathrm{C}$ agenda it would need to facilitate the transition from oil-based automobile dependence to renewable electrified rail transit though this may not be a simple or linear process, especially in emerging cities like in India. This article will look at whether the process is underway in Indian cities where considerable momentum to remain in an oilbased transport system has been the agenda for many decades. The article begins by looking at the overall picture in India with respect to fossil fuels and economic growth in comparison to other nations before examining the first Indian cities that have attempted to begin to build electric rail mass transit systems and use more solar in their systems.

The process of decoupling economic growth from use of fossil fuels is at the heart of the $1.5^{\circ} \mathrm{C}$ agenda. This process is already underway and the data on decoupling growth in wealth from growth in fossil fuels is now clearly showing not just a relative decoupling but an absolute decoupling globally and in most developed nations and cities (Newman, 2017a, 2017b; Newman, Beatley, \& Boyer, 2017). See Figure 1a on Denmark, which is perhaps a leader in the developed world though most European nations are similar and even America and Australia are now moving down this path.

However, the decoupling in China (Figure 1b) and India (Figure 1c) now becomes the key focus for global policy as their coupled growth can easily make the $1.5^{\circ} \mathrm{C}$ target impossible for the world due to their size and their leadership in the emerging world. The decoupling in China is led by strong top down policies and bottomup demand in their major cities which has led to rapid declines in coal and oil growth (Gao \& Newman, 2017). But India is less obviously decoupling and seems more poised to go either way; it is relatively decoupling and thus is demonstrating potential to go into absolute decoupling of wealth from coal and oil but could just continue growing also. Which outcome is likely is the underlying motivation behind this article.
This article will look at India and its growing cities to see whether a similar rapid decoupling trajectory can happen and whether the seeds for this transition are already present. The article will discuss the case of how Indian cities can contribute to the $1.5^{\circ} \mathrm{C}$ target through its rapid growth in electric urban rail and its commitment to solar. The transition is being formally expressed as: from 'oil-based automobile dependence' to 'urban rail plus renewable energy' whilst continuing to cater for transport demand in Indian cities. The changes will require two innovations that the article focuses on. First innovative financing of urban and intercity rail through land based private investment as funding of such projects has been a global challenge and is one India is now taking on. Second, enabling Indian cities to rapidly adopt solar energy for all its electrified transport systems rather than fossil fuel based. The article further briefly discusses electric vehicles (EV), collaborative consumption and urban planning implications that would contribute to the future ability of Indian cities to contribute to the $1.5^{\circ} \mathrm{C}$ agenda.

\section{India's Urban Transport Demand and Oil}

Urbanization is essential for driving economic growth (Glaeser, 2011). India is set to witness rapid urbanization in the next four decades with accompanying economic growth. India's urban population is projected to increase from 377 million in 2011 to 600 million by 2031 . This would mean India will have 87 cities over a million population by 2031 from the 50 in 2011 . The predicted urbanization and economic growth in India would possibly be the largest national urban transformation of the 21st century (Ahluwalia, 2011; Ahluwalia, Kanbur, \& Mohanty, 2014; Heilig, 2012; WBG, 2017).

India is predicted to play a key role in future oil demand growth due to increased car ownership driven by high income growth. While the proposed oil consumption has been anticipated by the Organization of the Petroleum Exporting Countries it would however result in financial and environmental adversity for India and would be a significant setback in assisting achieve the Paris Agreement. Financially it will be a problem as India imports over $75 \%$ of its total crude oil resulting in energy security, trade deficit and foreign exchange issues. Environmentally it is an issue due to air pollution that has been a significant public health issue in all major Indian cities. Traffic congestion, noise and associated externalities are attached to the predicted automobile increase as well. It is also essential for Indian cities to avoid oil-based automobile dependence in order to fulfil their Paris Agreement and make progressive steps towards the $1.5^{\circ} \mathrm{C}$ target (International Energy Agency, 2015; Van Moerkerk \& Crijns-Graus, 2016).

Private vehicles in Indian cities are dominated by two-wheelers and cars. Two-wheelers are the dominant private mode with over five times the number of twowheelers than cars in $2015 .{ }^{1}$ High dependence on private

\footnotetext{
${ }^{1}$ The mode shift from two-wheelers to transit has higher probabilities than car that help in the growth of transit, especially rail based.
} 
a)

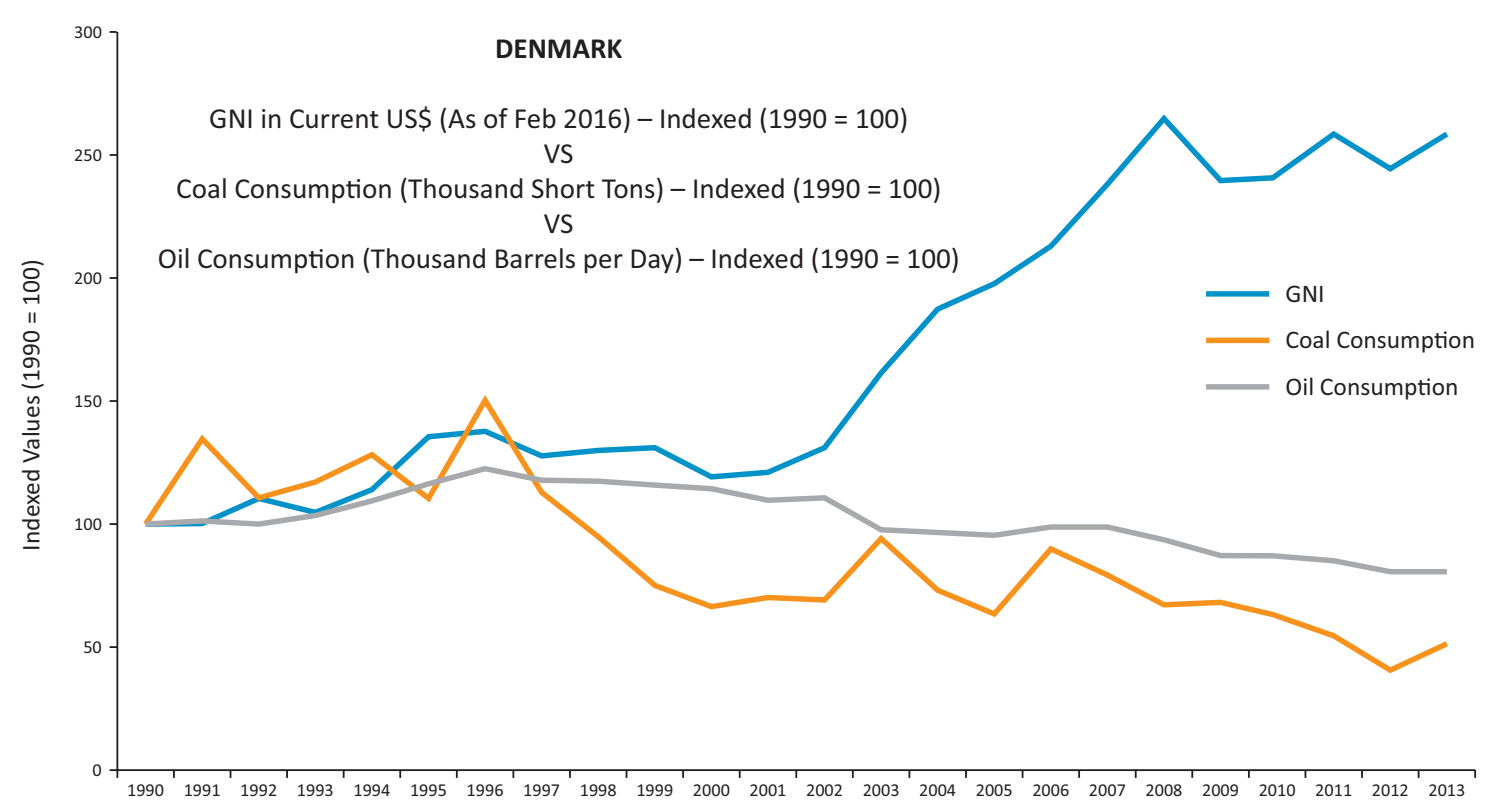

b)

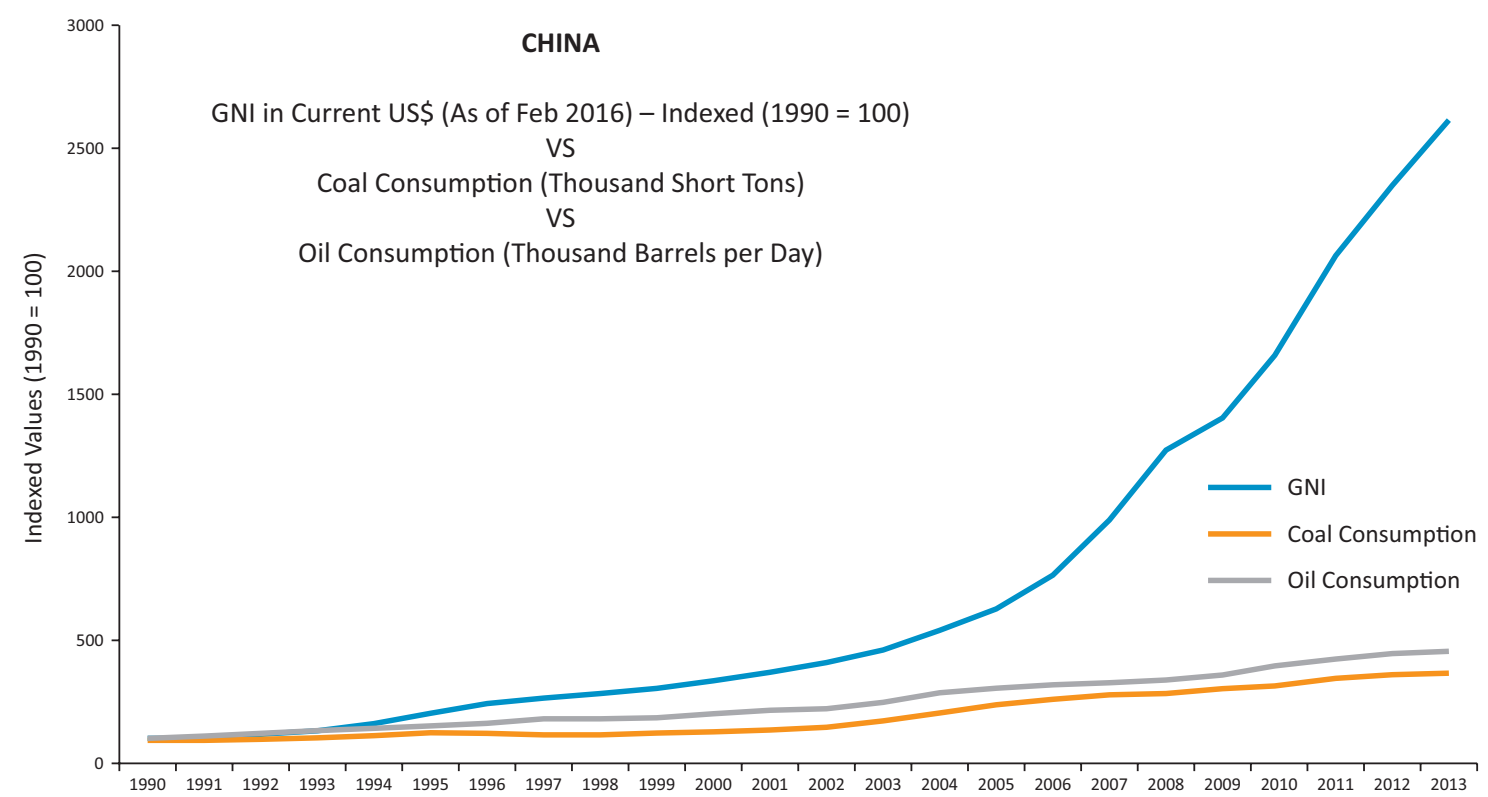

c)

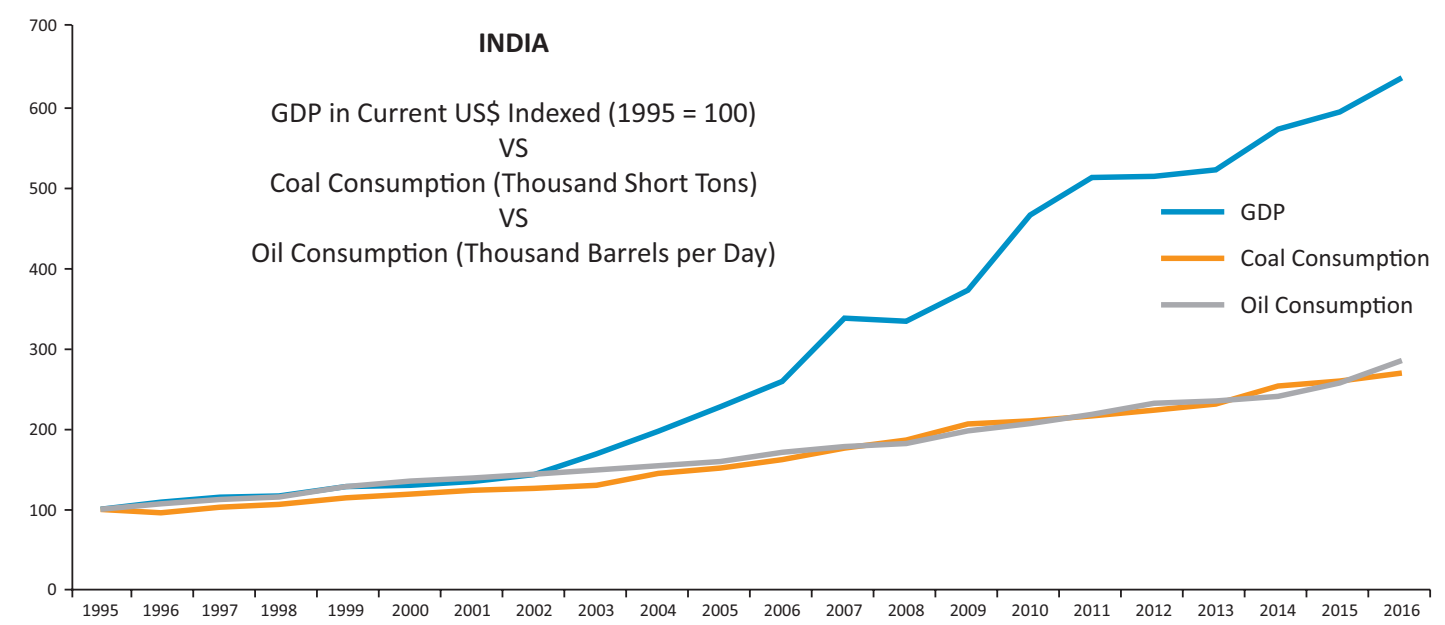

Figure 1. Decoupling wealth from coal and oil in Demark (a), China (b) and India (c). Note: GNI stands for Gross national income, which is almost equivalent to GDP but is more available in terms of data. Source: Compiled by author based on data sourced from CEID (2017), United States of America Energy Information Administration (EIA, 2016), Ministry of Petroleum \& Natural Gas (2017), Newman (2017b), OPEC (2016) and The Worldbank Group (WBG, 2016). 
vehicles has happened in the last two decades with a subsequent decline in public transport share but not totals as every available mode has been crowded with people during the rapid growth of Indian cities. $85 \%$ of the total private vehicles registered in India has happened between the years 1991 to 2011 . The private vehicle growth rate has been over $10 \%$ annually which is one of the highest globally; however, India is still low in-terms of per capita vehicle ownership on a global scale. ${ }^{2}$ The growth rate has been largest associated with high increases in income (Ahluwalia, 2017; Dhar \& Shukla, 2015; Goel, Mohan, Guttikunda, \& Tiwari, 2016).

Goel et al. (2016) show that registered vehicles in India are highly overestimated; they suggest that the actual number of in-use vehicles compared to officially registered is out by over $120 \%$. The findings of Goel et al. (2016) indicates that the wealth increase leading to vehicle ownership may not essentially mean the increase of private vehicle $\mathrm{km}$ in Indian cities. To understand this further I have plotted historic growth rates in Figure 2 of the gross domestic product, oil consumption, car registration and road length in India.

Figure 2 indicates that there has been exponential growth of car registration even more than the GDP growth. But this has not resulted in road length increase or increased oil consumption levels. This is consistent with the earlier Figure $1 \mathrm{c}$ which shows wealth is being relatively decoupled from oil. The big question is whether this can be turned into an absolute decline in oil.

\subsection{Automobile Saturation in Indian Cities?}

At a macro level (from Figure 2) it seems that Indian cities have intrinsic features that could be acting as a 'soft power' 3 to hinder the growth of vehicle kilometre travelled as compared to car registration. One possible factor is limited road space in Indian cities as like many emerging cities they are historically walking cities with all that associated fabric in density and mixed use (Newman et al., 2016).

As per the Census of India (2011) about $24 \%$ of the population work from home, ${ }^{4} 23 \%$ walk to work, $13 \%$ bike to work, $19 \%$ use public transport, $4 \%$ use a car and $17 \%$ use two-wheelers to go to work in Indian cities. A quarter of commuters travel less than $1 \mathrm{~km}$ and another third travel between two and five $\mathrm{km}$. This travel pattern shows that the majority of workers do not use any motorized mode to travel to work and travel short distances - reflecting the dense walking fabric and mixed land use in Indian cities (Rode et al., 2014; Tiwari, Jain, $\&$ Rao, 2016). Thus, Indian cities need to invest significantly to improve and build their walking and cycling infrastructure which is in poor condition and do not even cover major transit/road corridors in order to improve walking fabric (Ministry of Urban Development, 2013). An increase in walking and cycling mode share is critical for achieving climate changes goals in cities and as mentioned before in this article urban rail can facilitate this increase due to its ability to replace car use and its ability to

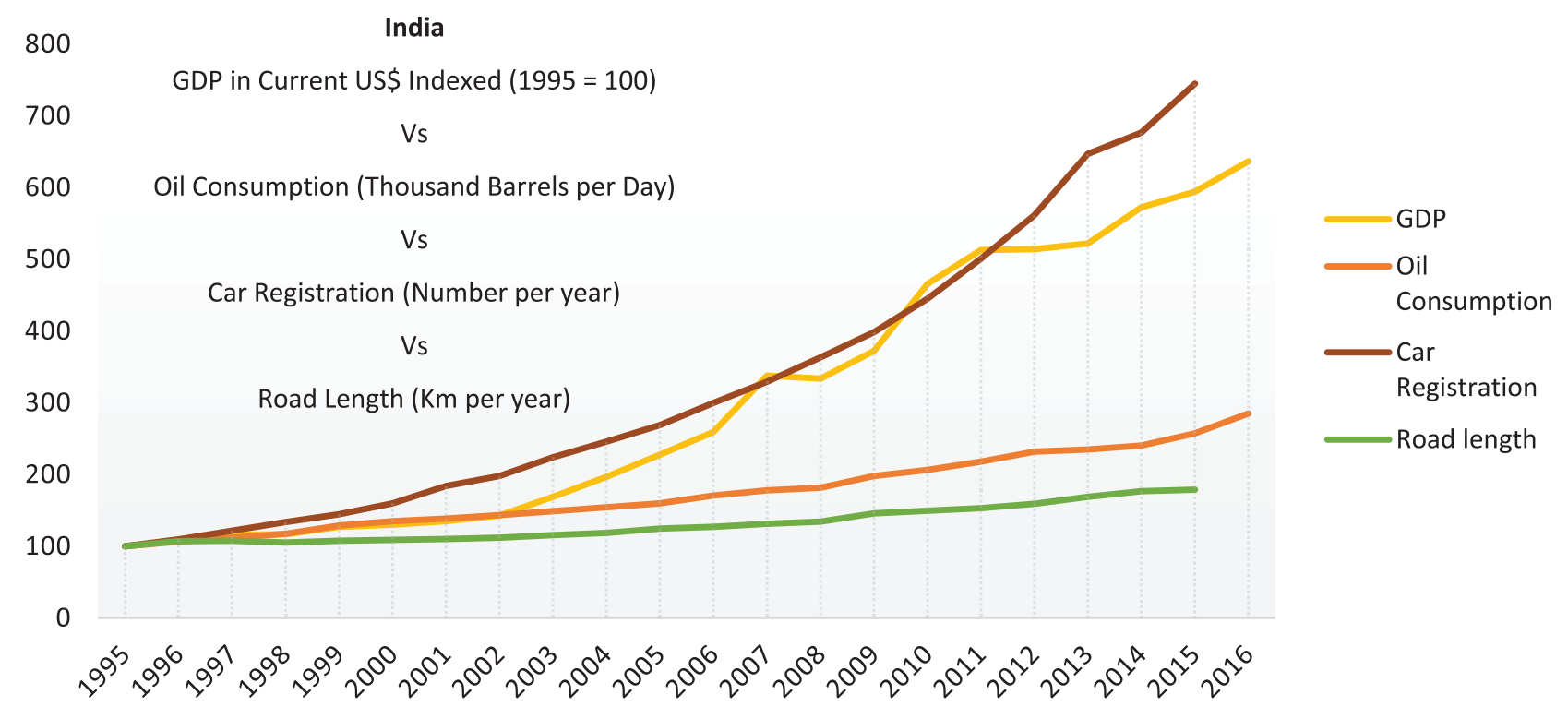

Figure 2. Historic growth rates of GDP, oil consumption, car registration and road length in India. Source: Compiled by author based on data sourced from CEID (2017), EIA (2016), Government of India (2017a), Ministry of Petroleum \& Natural Gas (2017), OPEC (2016) and WBG (2016).

\footnotetext{
${ }^{2}$ India's car ownership is about less than four times of China and less than twenty-five times of OECD countries.

${ }^{3}$ For this article we used the term 'soft power' (inspired from Joseph Nye's work) of cities: characteristics of a city to influence the travel behavior without push or coercion (Nye, 2004).

4 This could be possibly due to the traditional houses having shop and house on the same land, small business like tailors, tradesman and others are located within the residence.
} 
be funded from the facilitation of transit oriented developments due to the increased value in land around rail stations (Newman \& Kenworthy, 2015; Sharma \& Newman, 2018).

The 'soft power' characteristics of Indian citiestravel pattern, road length growth, and dense, mixed use urban fabric, seem to be the factors that could have ensured the start of decoupling wealth and car use. Even with a small per capita car ownership the urban fabric of Indian cities has resulted in high traffic congestion and low travel speed thus minimizing growth in the use of cars. It also suggests that without a massive road building program that completely alters the urban fabric (as happened in US cities) there is unlikely to be much more ability of Indian cities to cope with high traffic growth.

The travel speeds of private vehicles in various large Indian cities during peak hour is less than $15 \mathrm{~km} / \mathrm{hr}$ in most major corridors. This means that even the most basic of urban rail expansions and building would enable Indian residents to travel faster than in the road traffic. ${ }^{5}$ Urban rail in Indian cities has an average speed of over $35 \mathrm{~km} / \mathrm{hr}$. This would suggest that the big problem is automobile-saturation in Indian cities rather than automobile dependence as is the case in some Chinese cities (Gao \& Newman, 2017; Sharma \& Newman, 2017a). This is an easier problem to solve as the attraction of urban rail when it is built will be immediate and long lasting.

If the trend to decouple oil from wealth is to continue and accelerate into an absolute decoupling, then Indian cities will need to focus on building a lot more urban rail. As suggested here large Indian cities are looking for fast urban rail solutions to help overcome traffic problems which will increase the urban rejuvenation potential in their dense areas and land development opportunities. The question is whether the political will is there and whether financial mechanisms are available to make it happen.

\subsection{Public Transport and Economic Growth in Indian Cities}

The strong link between public transport and economic growth has become a major part of national and urban policy in recent decades (Glaeser, 2011; Glaeser, Kahn, \& Rappaport, 2008). This is now being widely recognized by Indian cities. Public transport service levels are currently low in Indian cities with a significant public transport supply gap of $240 \%$. This has contributed to the $21 \%$ mode share of private transport and $19 \%$ mode share of public transport. However, Mumbai's suburban rail is an example of how private vehicle use is restricted without it restricting economic growth (Government of India, 2014; Newman \& Kenworthy, 2015; NITI Aayog \& Rock Mountain Institute, 2017).

Mumbai's suburban rail-dominated public transport has restricted private vehicle use to $12 \%$ as compared to the $40 \%$ mode share for private vehicles in Delhi and Bangalore which had no significant urban rail presence in 2011 (Census of India, 2011). A brief analysis of $\mathrm{CO}_{2}$ emissions in Mumbai, Bangalore and Delhi show that if Bangalore and Delhi achieve similar mode share to Mumbai, which is dominated by rail, Delhi can cut urban transport emissions by $40 \%$ and Bangalore by $34 \%$. This analysis is based on Census of India, 2011 data for passenger km and $\mathrm{CO}_{2}$ intensity has been referred from Dhar, Pathak and Shukla (2018) as presented in Table 1.

Mumbai's low road density, high density of cars per $\mathrm{km}$ and high population density among all major Indian cities seems to have resulted in automobile-saturation and hence the dominance of transit mode share at about 79\% (Rode et al., 2008; Census of India, 2011). Mumbai has the highest per capita income, quality of life and productivity among all major Indian cities (UN-HABITAT, 2012) coinciding with the analysis of global cities on wealth increase and vehicle km growth by Newman and Kenworthy (2015). Mumbai shows how a rail based urban transport can cut emissions and increase wealth. The Indian government recognizes that densification linked with public transport is essential to sustain urbanization and economic growth (Ministry of Urban Development, 2014). This recognition has resulted in effective policy formulation at the federal government level paving way for over 50 Indian cities to plan for urban rail.

Chauvin, Glaeser, Ma and Tobio (2017) shows that there is a high correlation between density and earnings across Indian cities, that is stronger than in the U.S. cities.

Table 1. Passenger km and $\mathrm{CO}_{2}$ intensity in Mumbai, Bangalore and Delhi.

\begin{tabular}{|c|c|c|c|c|}
\hline \multirow[b]{2}{*}{ All Modes } & Mumbai \& Suburban & Bangalore & NCT of Delhi & \multirow[b]{2}{*}{$\mathrm{CO}_{2}$ Intensity $\left(\mathrm{tCO}_{2} / \mathrm{M} \mathrm{pkm}\right)$} \\
\hline & \multicolumn{3}{|c|}{ Passenger km (million) } & \\
\hline Moped/Scooter/Motor Cycle & 1.9 & 6.9 & 7.8 & 31.9 \\
\hline Car & 2.9 & 4.5 & 8.5 & 99.1 \\
\hline Bus & 7.4 & 9.9 & 14.2 & 14.6 \\
\hline Train & 21.5 & 0.5 & 3.0 & 14 \\
\hline
\end{tabular}

\footnotetext{
5 The travel speed and passenger carrying capacity per lane of urban rail is much higher than rubber-based transit. For this article rubber-based transit is not discussed as an option; this is seen as the mode which can help as a feeder to urban rail where the last mile distances are above 1-2km. The potential of urban rail to create high density transit orient development centres would mean walking as a main access mode to rail also and this is better for the $1.5^{\circ} \mathrm{C}$ agenda. Cities will always need to invest significantly to improve walking and cycling infrastructure around mass transit.
} 
Cities with higher density also tend to be more productive and have higher quality of life parameters. This density and income would be further facilitated with India's plan to implement urban rail in over 50 cities with aligned policies of land value capture (LVC) and density.

\section{India's Plans for Growth in Urban Rail}

In rapidly growing Indian cities urban rail has emerged as an efficient and reliable solution to cater to urban travel demand. The growth of India's modern urban rail system has happened in the last decade after the transitsuccess of Delhi Metro (started in 2002). Urban rail, in August 2017, is operational in 11 cities and under construction in another nine cities. Indian cities have added 370 $\mathrm{km}$ operational urban rail and another $556 \mathrm{~km}$ is underconstruction in the period of 2002-2017. This is far behind China's over $3,000 \mathrm{~km}$ of urban rail most of which was built in the past decade.
Indian cities have extensive plans $(712 \mathrm{~km})$ for urban rail as shown in Table 2. Delhi's $467 \mathrm{~km}$ urban rail network is planned to be constructed by 2021 and around 60\% of the city would be within 15-minute walking distance from the network. Mumbai Metropolitan Region plans to add over $192 \mathrm{~km}$ of urban rail network in addition to the existing $465 \mathrm{~km}$ of suburban rail by 2021 (Delhi Development Authority, 2007; Government of India, 2017b; Kai, Baoming, Fang, \& Zijia, 2016; MMRDA, 2017).

This growth is driven by demand for urban rail travel and supported through political leadership. The Indian government has been financially supporting urban rail since 2011 in cities with a population over two million but this norm has been reduced to one million to extend this benefit to medium size cities (Sharma \& Newman, 2017b). This is a good outcome for the $1.5^{\circ} \mathrm{C}$ agenda though it may not have been a part of the rationale for this decision.

Globally UIC, the International Railway Association

Table 2. Urban rail network in Indian cities.

\begin{tabular}{|c|c|c|c|c|c|c|}
\hline \multirow[b]{2}{*}{ SI No. } & \multirow[b]{2}{*}{ City } & \multirow{2}{*}{$\begin{array}{l}\text { Population } \\
\text { (in million) }\end{array}$} & \multirow[b]{2}{*}{ Urban Rail Project Name } & \multicolumn{3}{|c|}{ Urban Rail Network in km } \\
\hline & & & & Operational & Under Construction & Planned \\
\hline 1 & Delhi & 16.3 & \multirow{5}{*}{ Delhi Metro } & \multirow{5}{*}{218} & \multirow{5}{*}{$179 *$} & \multirow{5}{*}{$148^{*}$} \\
\hline 2 & Noida & 0.6 & & & & \\
\hline 3 & Ghaziabad & 1.1 & & & & \\
\hline 4 & Faridabad & 1.4 & & & & \\
\hline \multirow{2}{*}{5} & \multirow{2}{*}{ Gurgaon } & \multirow{2}{*}{8.7} & & & & \\
\hline & & & Rapid Metro & 12 & 0 & 0 \\
\hline \multirow{2}{*}{6} & \multirow{2}{*}{ Mumbai } & \multirow{2}{*}{12} & Mumbai Metro & 11 & 124 & 57 \\
\hline & & & Mumbai Monorail & 8 & 0 & 0 \\
\hline 7 & Kolkata & 4.4 & Kolkata Metro & 28 & 113 & \\
\hline 8 & Chennai & 4.6 & Chennai Metro & 28 & 19 & 104 \\
\hline 9 & Bangalore & 8.4 & Namma Metro & 42 & 34 & 57 \\
\hline 10 & Kochi & 0.6 & Kochi Metro & 13 & 26 & 37 \\
\hline 11 & Jaipur & 3 & Jaipur Metro & 10 & 2 & 23 \\
\hline 12 & Lucknow & 2.8 & Lucknow Metro & 0 & 33 & 140 \\
\hline 14 & Hyderabad & 6.8 & Hyderabad Metro & 0 & 72 & 168 \\
\hline 15 & Nagpur & 2.4 & Nagpur Metro & 0 & 19 & 38 \\
\hline 16 & Gandhinagar & 0.2 & \multirow{2}{*}{$\begin{array}{l}\text { Metro-Link Express for } \\
\text { Gandhinagar and Ahmedabad }\end{array}$} & \multirow{2}{*}{0} & \multirow{2}{*}{19} & \multirow{2}{*}{$3 \varepsilon$} \\
\hline 17 & Ahmedabad & 5.5 & & & & \\
\hline 18 & Kanpur & 2.7 & Kanpur Metro & 0 & 24 & 38 \\
\hline 19 & Navi Mumbai & 1.1 & Navi Mumbai Metro & 0 & 11 & 12 \\
\hline 20 & Pune & 3.1 & Pune Metro & 0 & 60 & 0 \\
\hline Total & & 84.6 & & 370 & 556 & 712 \\
\hline
\end{tabular}

Note: * includes Noida Metro and Ghaziabad Metro projects. Source: Compiled by author based on data from Census of India (2011) and Ministry of Urban Development $(2013,2014)$. 
(with 240 members worldwide), has proposed to improve the energy efficiency of the rail sector by a $50 \%$ reduction of final energy consumption from train operations by 2030 through technical measures, improved management, decarbonization of energy consumption and better use of existing rail assets. There are further energy savings to be achieved by using lighter weight/composite materials (30\% potential energy savings), and by optimizing energy recovery devices (up to $45 \%$ potential energy savings) and train operation management (Hoen et al., 2017). All these will contribute to the $1.5^{\circ} \mathrm{C}$ agenda and will reduce the life cycle emissions of urban rail.

\section{The Problem of Urban Rail Funding}

At the time when urban rail investment appears to be a priority for cities, governments across the world face budgetary pressure leading to challenges in the funding and financing of urban rail. Funding of urban rail through traditional gross budgetary support from the government seems increasingly difficult in the existing global economic scenario. This traditional way of urban rail investment will lead to a growing debt-subsidy cycle which would undermine economic development and minimize the possibility of India actually phasing out oil the way that the world needs in the $1.5^{\circ} \mathrm{C}$ agenda.

Existing Indian urban rail systems are facing a financial deficit as they are highly dependent on fare box revenue and conventional budgetary support from the government, as has been the case globally. Urban rail agencies have significantly struggled to recover even operating costs through fare box revenue as it is inherently limited due to equity demands (Flyvberg, 2007; Jillella, Matan, Sitharam, \& Newman, 2016; Sharma, Newman, \& Matan, 2015). This has resulted in fare increases in Delhi Metro and proposed fare increases in Mumbai Metro which have created community and political dissension. Mumbai is one city where the fare box may have been possible to cover all costs but even here it does not. It is thus essential for Indian cities to explore alternative funding sources. However, the role of urban rail in facilitating the $1.5^{\circ} \mathrm{C}$ agenda and creating better cities in general, is likely to be far more transformative than using other sustainable transport modes as it has an inherent ability to attract private funding through land development opportunities associated with rail systems. Urban rail's impact on land values and the potential of land development, rejuvenation and agglomeration benefits, suggest economic value can be captured by a range of LVC mechanisms (Banister \& Thurstain-Goodwin, 2011; Capello, 2011; Newman, Davies-Slate, \& Jones, 2017; Newman \& Kenworthy, 2015; Sharma \& Newman, 2017b).

LVC studies on urban rail projects provide evidence that both government and public private partnership (PPP) urban rail projects are financially viable and can maintain affordable fares through LVC-based funding mechanisms. Indian urban rail systems have shown sig- nificant uplift in land value at both a city and corridor level. Sharma and Newman's (2017a) hedonic price model on Bangalore Metro showed a $23 \%$ increase in land value in the $1 \mathrm{~km}$ catchment area of urban rail and of great significance it appears to have increased land values over the whole city by an average of $4.5 \%$. A study on Mumbai Metro showed a $14 \%$ increase in land value for properties between $1 \mathrm{~km}$ and $2 \mathrm{~km}$ from stations (Sharma \& Newman, 2018). Similar results were found on Chinese cities. Zhang, Liu, Hang, Yao and Shi (2016) panel data hedonic price model on housing prices of 35 Chinese cities from 2002 to 2013 showed that a 1\% increase in rail transit mileage improves housing prices by $0.023 \%$ at the city level. This shows urban rail's crucial role on land values and hence how various 'beneficiary pays' mechanisms could be tapped to rapidly increase urban rail investment.

Not only is there a clear case that urban rail increases land value around stations but the project life cycle of urban rail systems with their associated land uses, are generally longer than any road-based system and hence can attract private investment as there are long-term financial and economic benefits when the transit, land use and finance are integrated. Private sector involvement can address this multidisciplinary integration by bringing innovation, technology, design stage efficiency, market driven land development skills, improved operational efficiency and long-term value for money through risk sharing. These latter skills are not readily available within government. Private participation in urban rail projects has shown efficient exploitation of non-transport revenues such as advertisement, station area development and kiosks/shops at stations along with bringing efficiency in construction and operations when involved from the design stage. Bigger projects which depend on even more land development for private investment opportunities, require even more obvious ways of incorporating private bids on how best to do it. Involvement of the private sector at design stages can also enhance budget predictability for government (Bowman \& Ambrosini, 2000; Giuliano, 2004; Medda, 2012; Pojani \& Stead, 2015; Sharma et al., 2015).

Governments are therefore seeking private investments and partnerships to implement urban rail projects. This is based on rail's impact on urban land values providing value creation potential thus enabling land development to provide the returns needed by the private sector. Privately financed urban rail is being proposed and debated globally including Australia, India, Canada and the US.

Hyderabad Metro is one such urban rail being built on a Design Build Finance Operate Transfer agreement wherein a private developer was provided about $10 \%$ of the capital cost as grant (equity) from the federal government of India and the state/provisional government granted air-rights for commercial development of about 12.5 million sq. $\mathrm{ft}$. over the three depots and 6 million sq. ft. at the 25 selected stations. The private developer 
has raised capital through loans and equity. The private developer's concession period is for 35 years and the private developer was able to start renting the spaces before the rail was operational. This case shows the private sector's active approach towards enhancing revenue streams. This increase in non-fare box revenue may help maintain low transit fares in the long term based on a similar outcome that has been found in all of Japan's rail system and Hong Kong's Metro where private land development is used to keep fares low and fund the whole system (Newman, Davies-Slate, \& Jones, 2017; Sharma \& Newman, 2017b).

The Indian government recently approved three highly significant policies of relevance to the topic of this article: the National Transit Oriented Development Policy (Government of India, 2017c); the Value Capture Finance policy framework (Government of India, 2017d); and the Metro (urban rail) Policy (Government of India, 2017b). These policies were also necessary to realize the potential of significant investment in urban rail for future urbanization. Together these policies show the intent of the policy makers to enable density, urban rail, accessibility, urban agglomeration and land-based financing. These will assist in framing a supportive mobility oriented urban planning framework that can increase India's GDP by 1-6\% (NITI Aayog \& Rock Mountain Institute, 2017) whilst decoupling from automobile dependence and fossil fuels.

The Metro Policy of August 2017 (Government of India, 2017b) mandates Indian cities to involve 'private sector participation' and 'land value capture' in urban rail to access $10 \%$ equity funding from the federal government. Such approaches of mandatory private sector involvement will increase the private sector risk appetite. Private sector involvement from the concept stage for urban rail and land development can increase the redevelopment potential commitment from the private sector and lead the public sector to focus on their core role of governance including community engagement and partnership development. Community engagement should be seen as an essential component not an optional extra as this can enable political validation as well as improving local amenity through their detailed knowledge of needs and options and hence provide the basis for partnerships with government and business.

These are a significant set of policy decisions by the Indian government to maximize value creation from urban rail. This may also allow implementation of innovative contracting mechanisms such as the Entrepreneur Rail Model of Newman, Davies-Slate and Jones (2017). There are significant challenges for such processes to be implemented in Indian cities such as digitizing urban infrastructure maps, institutional integration in cities, land use and transit integration, land valuation (at plot level), digitization of land use maps and strategic planning frameworks. However, these are possible to add as the system grows and the key factor in tapping private funds to transform the urban rail market is to have the ability to create integrated partnerships between government at all levels and the private entrepreneurs in urban redevelopment as well as private rail operators. India has begun to do this.

The land development based financing and private sector participation outlined above is likely to help facilitate the expansion of urban rail in Indian cities, as long as urban planning tools are used to help and not hinder this process. This rail growth would enable economic growth while decoupling car use. Indian cities have the advantage that their walking and transit urban fabric are already ideal to be served by urban rail. Thus, these policies are likely to lead to a decline in oil consumption whilst enabling economic growth to accelerate. Urban fabric benefits should mean that the extra wealth will go into using easier ways to enable urban rail as happened in China, and wealth will come to be associated with 'rail not car'. These rail systems would need to be renewable based along with other modes of urban transport to contribute to the $1.5^{\circ} \mathrm{C}$ target, we discuss these in the next sections.

\section{Solar in Indian Rail}

To contribute to the $1.5{ }^{\circ} \mathrm{C}$ target urban rail systems should operate on renewable energy, specifically solar in the Indian case. Electric urban rail systems are nonsite emitters. Their emissions depend upon the type of fuel used for the generation of electricity which is currently coal dominated in the case of India. However solar is rapidly competing with coal for Indian urban rail operations.

India plans to generate 175 gigawatts (GW) of renewable energy by $2022-100 \mathrm{GW}$ to come from solar. According to Morgan Stanley (2017) solar power is becoming more affordable than electricity generated from coal power generators. This is significant as India is the thirdlargest source of carbon emissions. The key argument for using coal was that it is affordable and accessible in India but now with solar being $18 \%$ cheaper than coal the Indian energy sector is on the edge of a major transformation (Farand, 2017). The Indian government has shown it intends to reduce coal consumption by doubling the 'Clean Environment Cess' on coal in year 2017 budget, and by initiating the International Solar Alliance which is envisaged as an inter-government treaty between solar resource-rich countries aimed at efficient exploitation of solar energy to reduce dependence on fossil fuels and to mobilize USD 1 trillion for it (Ministry of Finance, 2017; UNFCCC, 2017).

India has started relative decoupling in the past decade of Coal and GDP as shown in Figure 1c. The growth of coal has slowed and may change to an absolute decline as India invests strongly in renewables and urban electric rail. Ben Caldecott (2017) from Oxford University suggests that Indian power company's investments in coal are financially unviable whilst solar would be a future investment with many economic benefits. This sug- 
gests that Indian economic growth has clear potential to be based around renewable sources rather than fossil fuels leading into the future.

The most recent urban rail system of India - the Kochi Metro-has rooftop solar on all of its rail stations to meet $25 \%$ of its electricity requirement. Delhi Metro (urban rail) started in 2002 and thus had negligible solar panels then but now meets $80 \%$ of its daytime energy from solar (Energy World, 2017; Sood \& Bhaskar, 2017). The recent decline of the cost of energy storage systems may assist the further use of solar energy for urban rail systems. New TODs being built around stations need to be covered in solar with battery storage in the area as is happening in various demonstration sites such as Bordeaux and Boulder, Colorado. The next generation urban rail systems are predicted to be powered by solar and batteries with electric power through high-powered contactless charging at stations (Newman \& Kenworthy, 2015).

Indian Railways has also started the process to modernize their existing inter-city railway stations through PPPs. The modernization process will include mixed land use development, maximized solar energy utilization and a focus on non-fare box revenue. The proposed fast-rail along urban growth corridors in India, such as the Rapid Rail Corridor around Delhi, are incorporating solar energy and LVC within the planning and design stage of the project.

The Indian government in their 2017 budget has committed to install rooftop solar in 7,000 inter-city rail stations. This is a significant commitment. The first 300 stations have had solar panels installed (Ministry of New and Renewable Energy, 2017). A recent trial of solar panels on the roof of Indian trains has been made to reduce the energy requirement for wagon's lighting and fans but not for locomotives.

Electric trains with batteries are likely to be another trial especially in smaller trains. Newman (2017a) suggests that this transformation may happen much quicker as the demand for renewables is high and cost of solar and batteries are on a rapid decline curve. Economic growth appears to be substantially changing to being based around renewable energy rather than the fossil fuel-based economic growth of the past 15 years.

\section{Electric Mobility}

The EV market is growing globally at over $40 \%$ per year. In India there is currently a negligible presence of EV at $0.0004 \%$ of its total vehicles as compared to Norway's $23 \%$, the Netherland's 6\% and China's $1.4 \%$ share of EV (International Energy Agency, 2017).

India's National Electric Mobility Mission Plan recognizes that the growth of EV's is critical for the energy transition in India as this will reduce oil imports and help with the air quality problem. As part of the mission the Indian government is providing financial incentives, subsi- dies and tax rebates to EV users and manufacturers to increase EV presence in India. The Indian government has provided over 30 million USD subsidy for $154,557 \mathrm{EV}$ as of August 2017. India's domestic manufacturing capacity of EV is growing with two-wheelers and cars. However, there is no manufacturing unit for electric buses despite some cities having introduced electric buses on a pilot basis (Dhar, Pathak, \& Shukla, 2017; National Automobile Board, 2017).

India has set a goal of 6-7 million EV by 2020 which is higher than China's goal of 5 million. The recent target of India is for all-electric mobility by 2030 . This ambitious goal is aimed to provide large economic benefits. NITI Aayog and Rock Mountain Institute (2017) notes that with electric and shared vehicles India can save 100 USD billion annually in fossil fuel foreign exchange and cut 1 GT carbon emission by 2030 (PIB India, 2017; Sharma, Kulkarni, Veerendra, \& Karthik, 2016).

Unlike developed countries, EV in India are dominated by two-wheelers and recently by E-Rickshaws that act as an intermediate public transport for short distances $(\sim 2 \mathrm{~km})$. Delhi's subsidy of 470 USD for each E-Rickshaw is significant for shared-electric public transport in that it also acts as a feeder system to urban rail such as Delhi Metro (Rokadiya \& Bandivadekar, 2016). Such EV vehicles can be efficiently used in smaller Indian cities where travel distances are shorter.

The critical challenge for Indian cities in enabaling EV growth would be providing EV infrastructure in urban planning schemes. In 2016, India only has 328 publicly accessible charging stations which hasn't increased since 2014. Cities would need to play an active role in regard to EV infratructure and can start with pilot city projects as in the case of other countries. India's abundance of solar enegy potential is an opportunity as with only $1 \%$ land area of Rajasthan (Indian State) could power the entire EV fleet traffic by 2030 on solar power (International Energy Agency, 2017; PIB India, 2017).

\section{Collaborative Consumption}

Collaborative consumption is a growing world phenomenon. ${ }^{6}$ It is likely to take over much of the growth in the private urban transport sector and create instead shared transportation options. Its most important function is likely to be the 'first mile last mile' service that links people to fast urban rail services. The shared systems can use smart cards to enable a combination of modes that can provide good mobility options including the urban rail services themselves. Thus the future is likely to see city rail and multi-modal local systems integrated around stations and centres. EV shared systems are already operating in many global cities and are on the rise with many cities planning for them. Cities with bike sharing schemes have increased from 4 in 2001 to over 1,000 in 2016 globaly (Tiwari, 2017).

\footnotetext{
${ }^{6}$ Collaborative consumption is phenomena born of the Internet age driven by information and communication technologies: the peer-to-peer-based activity of obtaining, giving, or sharing the access to goods and services, coordinated through community-based online services.
} 
Technological advancements in recent years have resulted in several cycling start-up companies in India such as Zoom-Pedl, Mobike, Ola-Pedal, Mobycy and Yulu. Mobycy is a recent mobile-app based bicycle sharing platform which allows commuters to unlock a bicycle parked in a dockless way at public places through a mobile-app generated QR code. It has started operations in Gurgaon with a fleet of 5,000 cycles and plans to spread in other major Indian cities. This can contribute to reducing oil based transport along with the other innovations mentioned above.

\section{Discussion: Urban Planning Implications}

The transitions that are underway in Indian cities towards urban rail expansion, the involvement of private investment based on LVC through TODs, the rapid growth of solar and battery storage in new urban developments, the growth of EVs and shared mobility, are all subjects that need urban planning to facilitate. A series of structural reforms and policy interventions would need to follow from Indian cities to support this transition, all with a strong partnership between citizens, government and industry.

All the major tools of urban planning will be needed to help make Indian cities contribute to the $1.5^{\circ} \mathrm{C}$ agenda as well as to develop economically and sustainably. Tools needed include:

1. Tools that ensure equity in housing policies and planning regulations to ensure that not only the wealthy benefit from transit systems and transitoriented development;

2. Tools to ensure that pedestrian qualities and good building design are features of all the new development around stations;

3. Tools to ensure that transport, land use and finance can be integrated at all stages of the planning process.

A committee (Ahluwalia, 2011) of the Indian government notes that transport, land use and other urban infrastructure are not planned in an integrated way which makes the integration of EV, TODs and urban rail challenging. Shared EV would require parking spaces and integration with transit and publicly accessible charging stations that would need to be addressed in an integrated manner at the city level in urban plans. More importantly, as outlined above, urban planning needs to facilitate partnerships as much of the planning needs to begin with private sector involvement in highlighting the best redevelopment options that urban rail can unlock in a funding partnership.

Recent research on integration between information and communications technology and spatial planning technology is showing the potential to integrate energy, transport and urban planning. Such technologies may help cities create more integrated planning of ur- ban infrastructure. This is on the government agenda in countries such as Australia (Commonwealth of Australia, 2017; Mosannenzadeh et al., 2017; Plume, Simpson, Owen, \& Hobson, 2015; Yamamura, Fan, \& Suzuki, 2017).

\section{Conclusion}

India has made a strong start on the transition from 'oil-based automobile dependence' to 'urban rail plus renewable energy'. The Indian government policy to make mandatory private participation and LVC may result in transformative higher density urban redevelopment projects that can fund many of these urban rail and solar projects. This would lead to greater economic gains and agglomeration benefits. Such processes may deepen the correlation of wealth, density and urban rail with reduced oil-based automobile dependency. The key issue will remain in the implementation of such policies and the financial viability of such projects, however Sharma and Newman $(2017 b, 2018)$ and the existing Hyderabad case suggest that with existing LVC legislation private-led urban rail can be financially viable.

The critical level of air pollution in Indian cities coupled with energy security issues can lead to rapid adoption of electric based transport modes in automobile saturated Indian cities. Considering the travel patterns in Indian cities the shared-EV, bike sharing and E-Rickshaws could potentially act as a feeder into any expanded urban rail system. This can cater for the majority of motorized travel in major Indian cities in coming decades. Innovative models of shared and connected urban transport systems with a high level of access to smart technology to end-users may enhance seamless integration of multiple modes within each city.

The continuation of these trends will require a combination of different forms of solar-based power and cities would need to integrate and organize such processes into urban planning schemes and different forms of urban fabric (Newman, 2017a, 2017b). As outlined, there are many signs of this beginning in India.

India has started relative decoupling of income and fossil fuel in the past decade which may change to an absolute decline in fossil fuels in coming years. Indian cities are thus likely to contribute to the $1.5^{\circ} \mathrm{C}$ agenda based on their urban fabric (inherently low in automobile dependence), electric urban rail growth through financing from land development and public private participation, increased walking and cycling, and the commitment to solar/battery-based mass transit and EV.

\section{Acknowledgments}

Funding for research was provided by Curtin University Sustainability Policy Institute (CUSP), Curtin University, through the provision of a PhD scholarship to Rohit Sharma. This article is one of a series of papers, as part of the PhD on Financing Urban Rail Projects through Land Value Capture-The Indian Case. 


\section{Conflict of Interests}

The author declares no conflict of interests.

\section{References}

Ahluwalia, I. J. (2011). High power expert committee report on urban infrastructure. New Delhi: Government of India Planning Commission.

Ahluwalia, I. J. (2017). Urban governance in India. Journal of Urban Affairs, 1-20. http://dx.doi.org/10.1080/ 07352166.2016.1271614

Ahluwalia, I. J., Kanbur, R., \& Mohanty, P. K. (2014). Urbanisation in India: Challenges, opportunities and the way forward. New Delhi: SAGE Publications.

Banister, D., \& Thurstain-Goodwin, M. (2011). Quantification of the non-transport benefits resulting from rail investment. Journal of Transport Geography, 19(2), 212-223. https://doi.org/10.1016/ j.jtrangeo.2010.05.001

Bowman, C., \& Ambrosini, V. (2000). Value capture versus value capture: Towards a coherent definition of value in strategy. British Journal of Management, 11, 1-15. https://doi.org/10.1111/1467-8551.00147

Caldecott, B. (2017). Why Indian power companies must dump coal and bet big on solar, wind. Hindustan Times. Retrieved from www.hindustantimes.com/ opinion/why-indian-power-companies-must-dumpcoal-and-bet-big-on-solar-wind/story-k933BI7zNE82 gV17tVXMLN.html

Capello, R. (2011). Location, regional growth and local development theories. AESTIMUM, 58, 1-25. Retrieved from www.fupress.net/index.php/ceset/ article/download/9559/8912

CEID. (2017). India registered motor vehicles: Cars, jeeps and taxies. CEID. Retrieved from www.ceicdata.com/ en/indicator/india/data/registered-motor-vehiclescars-jeeps-and-taxies

Census of India. (2011). Houselisting and housing census data 2011. Census of India. Retrieved from www. censusindia.gov.in/2011census/hlo/HLO_Tables.html

Chauvin, J. P., Glaeser, E., Ma, Y., \& Tobio, K. (2017). What is different about urbanization in rich and poor countries? Cities in Brazil, China, India and the United States. Journal of Urban Economics, 98, 17-49. http://dx.doi.org/10.1016/j.jue.2016.05.003

Commonwealth of Australia. (2017). Value capture: Is there a role for the commonwealth? The Hon Paul Fletcher MP. Retrieved from minister.infrastructure. gov.au/pf/speeches/2017/pfs002_2017.aspx

Delhi Development Authority. (2007). Master plan for Delhi, 2021. New Delhi: Delhi Development Authority. Retrieved from https://dda.org.in/ddanew/ pdf/Planning/reprint\%20mpd2021.pdf

Dhar, S., Pathak, M., \& Shukla, P. R. (2017). Electric vehicles and India's low carbon passenger transport: A long-term co-benefits assessment. Journal of Cleaner Production, 146, 139-148. https://doi.org/10.1016/ j.jclepro.2016.05.111

Dhar, S., Pathak, M., \& Shukla, P. R. (2018). Transformation of India's transport sector under global warming of $2{ }^{\circ} \mathrm{C}$ and $1.5^{\circ} \mathrm{C}$ scenario. Journal of Cleaner Production, 172, 417-427. https://doi.org/10.1016/ j.jclepro.2017.10.076

Dhar, S., \& Shukla, P. R. (2015). Low carbon scenarios for transport in India: Co-benefits analysis. Energy Policy, 81, 186-198. https://doi.org/10.1016/ j.enpol.2014.11.026

EIA. (2016). Total annual coal consumption: Thousand short tons. EIA Beta International-Countries Data. Washington, DC: EIA.

Energy World. (2017). From solar panels to vertical garden: Kochi Metro's five 'firsts' that make it unique. Economic Times. Retrieved from energy.economic times.indiatimes.com/news/renewable/from-solarpanels-to-vertical-garden-kochi-metros-five-firsts-that -make-it-unique/59188448

Farand, C. (2017). Solar energy prices in India tumbles to new record low making it cheaper than fossil-fuel generated power. Independent. Retrieved from www. independent.co.uk/environment/solar-energy-prices -india-drop-record-low-cheaper-fossil-fuel-powerphelan-aaada-bhadla-plyush-goyal-a7730226.html

Flyvberg, B. (2007). Cost overruns and demand shortfalls in urban rail and other infrastructure. Transportation Planning and Technology, 30(1), 9-30. https://doi.org/10.1080/03081060701207938

Gao, Y., \& Newman, P. (2017). Are Beijing and Shanghai automobile dependent cities? Paper presented at the Curtin University Sustainability Policy Institute, Perth.

Giuliano, G. (2004). Land use impacts of transportation investments. In S. Hanson \& G. Giuliano (Eds.), The geography of urban transportation (3 ed., pp. 237-273). New York, NY: Guilford Press.

Glaeser, E. (2011). Triumph of the city: How our greatest invention makes us richer, smarter, greener, healthier, and happier. New York, NY: Penguin.

Glaeser, E. L., Kahn, M. E., \& Rappaport, J. (2008). Why do the poor live in cities? The role of public transportation. Journal of urban Economics, 63(1), 1-24. https://doi.org/10.1016/j.jue.2006.12.004

Glaeser, E. L., \& Xiong, W. (2017). Urban productivity in the developing world. Oxford Review of Economic Policy, 33(3), 373-404.

Goel, R., Mohan, D., Guttikunda, S. K., \& Tiwari, G. (2016). Assessment of motor vehicle use characteristics in three Indian cities. Transportation Research Part D: Transport and Environment, 44, 254-265. http://dx.doi.org/10.1016/j.trd.2015.05.006

Government of India. (2014). National transport development policy committee. Planning Commission, Government of India. Retrieved from planning commission.nic.in/sectors/index.php?sectors=Nation al\%20Transport\%20Development\%20Policy\%2Com mittee\%20 
Government of India. (2017a). Total number of registered motor vehicles in India. Datagov India. Retrieved from https://data.gov.in/catalog/totalnumber-registered-motor-vehicles-india

Government of India. (2017b). Union cabinet approves new metro rail policy. Press Information Bureau. Retrieved from pib.nic.in/newsite/pmreleases.aspx ?mincode $=61$

Government of India. (2017c). Ministry of UD to push dense urban growth along mass transit corridors for better living experience. Press Information Bureau. Retrieved from pib.nic.in/newsite/Print Release. aspx? relid $=158690$

Government of India. (2017d). Value capture finance policy framework. New Delhi: Government of India. Retrieved from http://moud.gov.in/upload/whats new/5901c83d17591VCFPolicyFrameworkFINAL.pdf

Heilig, G. K. (2012). World urbanisation prospects: The 2011 revision. New York, NY: United Nations. Retrieved from http://www.un.org/en/development/ desa/population/publications/pdf/urbanization/WUP 2011_Report.pdf

Hoen, A., van Grinsven, A., Kampman, B., Faber, J., van Essen, H., \& Skinner, I. (2017). Research for TRAN Committee: Decarbonisation of EU transport. Brussels: Policy Department for Structural and Cohesion Policies of the European Parliament. Retrieved from www.europarl.europa.eu/RegData/etudes/STUD/20 17/601989/IPOL_STU\%282017\%29601989_EN.pdf

International Energy Agency. (2015). India outlook energy. Paris: IEA Publications. Retrieved from https:// www.iea.org/publications/freepublications/publica tion/IndiaEnergyOutlook_WEO2015.pdf

International Energy Agency. (2017). Global EV outlook 2017. Paris: IEA Publications. Retrieved from https://www.iea.org/publications/freepublications/ publication/GlobalEVOutlook2017.pdf

Jillella, S. S. K., Matan, A., Sitharam, T. G., \& Newman, P. (2016). Emerging value capture innovative funding and financing: A framework. In B. U. Rai (Ed.), Handbook of research on emerging innovations in rail transportation engineering (pp. 130-145). Hershey, PA: IGI Global.

Kai, L. U., Baoming, H. A. N., Fang, L. U., \& Zijia, W. A. N. G. (2016). Urban rail transit in China: Progress report and analysis (2008-2015). Urban Rail Transit, 2(3/4), 93-105. http://dx.doi.org/10.1007/s40864016-0048-7

Lu, S. M. (2015). Energy-saving potential analysis and assessment on land transport of Taiwan. Case Studies on Transport Policy, 3(4), 468-476. http://dx.doi.org/ 10.1016/j.cstp.2015.11.003

Matan, A., \& Newman, P. (2016). People cities: The life and legacy of Jan Gehl. Washington, DC: Island Press.

Medda, F. (2012). Land value capture finance for transport accessibility: A review. Journal of Transport Geography, 25, 154-161. http://dx.doi.org/10.1016/ j.jtrangeo.2012.07.013
MMRDA. (2017). Mumbai metro master plan. MMRDA. Retrieved from https://mmrda.maharashtra.gov.in/ mumbai-metro-rail-project\#

Ministry of Finance. (2017). Economic survey 201617. India Budget. Retrieved from indiabudget.nic.in/ es2016-17/echapter.pdf

Ministry of New and Renewable Energy. (2017). Renewable energy. New Delhi: Ministry of New and Renewable Energy. Retrieved from mnre.gov.in/filemanager/akshay-urja/january-april-2017/EN/Images /Akshay\%20Urja_February-April\%20\%2716_English .pdf

Ministry of Petroleum \& Natural Gas. (2017). Petroleum planning \& analysis cell ready reckoner. New Delhi: Ministry of Petroleum \& Natural Gas. Retrieved from ppac.org.in/WriteReadData/Reports/201706301015 077775859ReadyReckoner,June2017.pdf

Ministry of Urban Development. (2013). Urban transport service level benchmarking for Indian cities. New Delhi: Ministry of Urban Development, Government of India.

Ministry of Urban Development. (2014). National urban transport policy, 2014. New Delhi: Ministry of Urban Development, Government of India. Retrieved from itdp.in/wp-content/uploads/2014/11/NUTP-2014.pdf

Mosannenzadeh, F., Bisello, A., Vaccaro, R., D’Alonzo, V., Hunter, G. W., \& Vettorato, D. (2017). Smart energy city development: A story told by urban planners. Cities, 64, 54-65. https://doi.org/10.1016/ j.cities.2017.02.001

National Automobile Board (2017). National mission on electric mobility. Fame India. Retrieved from www.fame-india.gov.in

Newman, P. (2017a). The rise and rise of renewable cities. Renewable Energy and Environmental Sustainability, 2, 10. https://doi.org/10.1051/rees/2017008

Newman, P. (2017b). Decoupling economic growth from fossil fuels. Modern Economy, 8, 791-805. https:// doi.org/10.4236/me.2017.86055

Newman, P., Beatley, T., \& Boyer, H. (2017). Resilient cities: Overcoming fossil fuel dependence. Washington, DC: Island Press.

Newman, P., Davies-Slate, S., \& Jones, E. (2017). The entrepreneur rail model: Funding urban rail through majority private investment in urban regeneration. Research in Transportation Economics. https:// doi.org/10.1016/j.retrec.2017.04.005

Newman, P., \& Kenworthy, J. (2015). The end of automobile dependence: How cities are moving beyond carbased planning. Washington, DC: Island Press.

Newman, P., Kosonen, L., \& Kenworthy, J. (2016). Theory of urban fabrics: Planning the walking, transit/public transport and automobile/motor car cities for reduced car dependency. Town Planning Review, 87(4), 429-458. https://doi.org/10.3828/tpr.2016.28

NITI Aayog, \& Rocky Mountain Institute. (2017). India leaps ahead: Transformative mobility solutions for all. Rocky Mountain Institute. Retrieved from https:// 
www.rmi.org/insights/reports/transformative_mobil ity_solutions_india

Nye, J. S. (2004). Soft power: The means to success in world politics. New York, NY: PublicAffairs.

OPEC. (2016). Annual statistical bulletin. Vienna: Organization of the Petroleum Exporting Countries. Retrieved from https://www.opec.org/opec_web/ static_files_project/media/downloads/publications/ ASB2016.pdf

PIB India. (2017). Shri Piyush Goyal reiterates India's commitments to combat climate change at the world conference on environment 2017. Press Information Bureau. Retrieved from http://pib.nic.in/newsite/ PrintRelease.aspx?relid=159961.

Plume, J., Simpson, R., Owen, R. L., \& Hobson, A. (2015). Integration of geospatial and built environmentnational data policy. buildingSMART Australasia \& Spatial Industries Business Association. Retrieved from https://eprints.qut.edu.au/87944

Pojani, D., \& Stead, D. (2015). Sustainable urban transport in the developing world: Beyond megacities. Sustainability, 7, 7784-7805. https://doi.org/ 10.3390/su7067784

Rode, P., Floater, G., Thomopoulos, N., Docherty, J., Schwinger, P., Mahendra, A., \& Fang, W. (2014). Accessibility in cities: Transport and urban form (NCE Cities Paper 03, LSE Cities). London: London School of Economics and Political Science. Retrieved from https://files.Isecities.net/files/2014/11/LSE-Cities2014-Transport-and-Urban-Form-NCE-Cities-Paper-03. pdf

Rode, P., Wagner, J., Brown, R., Chandra, R., Sundaresan, J., Konstantinou, C., . . Shankar, P. (2008). Integrated city making: Governance, planning and transport. London: LSE Cities, School of Economics and Political Science.

Rokadiya, S., \& Bandivadekar, A. (2016). Hybrid and electric vehicles in India current scenario and market incentives (Working Paper). The International Council on Clean Transportation. Retrieved from https:// smartnet.niua.org/sites/default/files/resources/India -hybrid-and-EV-incentives_working-paper_ICCT_271 22016.pdf

Sharma, K. V., Kulkarni, M., Veerendra, G. P., \& Karthik, N. (2016). Trends and challenges in electric vehicles. International Journal of Innovative Research in Science, Engineering and Technology, 5(5). 8589-8596. https://doi.org/10.15680/IJIRSET.2016.0505281

Sharma, R., Newman, P., \& Matan, A. (2015). Urban railIndia's great opportunity for sustainable urban development. Paper presented at the European Transport Conference 2015. Association for European Transport (AET).

Sharma, R., \& Newman, P. (2017a). Urban rail and sustainable development key lessons from Hong Kong, New York, London and India for emerging cities. Transportation Research Procedia, 26, 92-105. https://doi.org/10.1016/j.trpro.2017.07.011
Sharma, R., \& Newman, P. (2017b). Does rail increase land value in emerging cities? Value uplift from Bangalore metro. Transport Research A: Policy and Practice. Manuscript submitted for publication.

Sharma, R., \& Newman, P. (2018). Can public private participation urban rail projects be competitive in speed and fare through land value capture? A Mumbai case study. Transport Policy, 64, 123-131. https://doi.org/10.1016/j.tranpol.2018.02.002

Sims, R., Schaeffer, R., Creutzig, F., Cruz-Núñez, X., D’Agosto, M., Dimitriu, D., ... Tiwari, G. (2014). Transport in climate change 2014: Mitigation of climate change. Contribution of Working Group III to the fifth assessment report of the intergovernmental panel on climate change. Cambridge, New York, NY: Cambridge University Press.

Sood, J., \& Bhaskar, U. (2017). DMRC's Rewa solar power plan runs into trouble. Livemint. Retrieved from www.livemint.com/Industry/PWbleRZmACrfog $3 Z 2 Q$ N5NL/DMRCs-Rewa-solar-power-plan-runs-into-trou ble.html

Stanley, M. (2017). Renewables energy hits global tipping point. Morgan Stanley. Retrieved from https:// www.morganstanley.com/ideas/solar-wind-renew able-energy-utilities

Tiwari, G., Jain, D., \& Rao, K. R. (2016). Impact of public transport and non-motorized transport infrastructure on travel mode shares, energy, emissions and safety: Case of Indian cities. Transportation Research Part D: Transport and Environment, 44, 277-291. https://doi.org/10.1016/j.trd.2015.11.004

Tiwari., R. (2017). Connecting places, connecting people: A paradigm for urban living in the 21st century. New York, NY: Taylor \& Francis.

UNFCCC. (2017). International solar alliance mobilizing USD 1 trillion for solar energy by 2030. UNFCCC. Retrieved from newsroom.unfccc.int/Ipaa/renewableenergy/international-solar-alliance

UN-HABITAT. (2012). State of the world's cities 2012/2013. Sustainable Development. Retrieved from https://sustainabledevelopment.un.org/con tent/documents/745habitat.pdf

Van Audenhove, F. J., Korniichuk, O., Dauby, L., \& Pourbaix, J. (2014). The future of urban mobility 2.0: Imperatives to shape extended mobility ecosystems of tomorrow. Brussels: UITP. Retrieved from http:// www.uitp.org/sites/default/files/members/140124\% 20Arthur\%20D.\%20Little\%20\%26\%20UITP_Future\%2 0of\%20Urban\%20Mobility\%202\%200_Full\%20study. pdf

Van Moerkerk, M., \& Crijns-Graus, W. (2016). A comparison of oil supply risks in EU, US, Japan, China and India under different climate scenarios. Energy Policy, 88, 148-158. https://doi.org/10.1016/ j.enpol.2015.10.015

WBG. (2016). Total gross national income (GNI) - Current \$US. World Development Indicators. Retrieved from https://data.worldbank.org/indicator/NY.GNP.MKTP.CD 
WBG. (2017). Urbanization in India. World Bank. Retrieved from web.worldbank.org/archive/website01 291/WEB/0_CO-22.HTM

Yamamura, S., Fan, L., \& Suzuki, Y. (2017). Assessment of urban energy performance through integration of BIM and GIS for smart city planning. Procedia Engineering, 180, 1462-1472. https://doi.org/10.1016/ j.proeng.2017.04.309

Yigitcanlar, T. (2010). Making space and place for the knowledge economy: Knowledge-based development of Australian cities. European Planning Studies, 18(11), 1769-1786. http://dx.doi.org/10.1080/ 09654313.2010 .512163

Zhang, X., Liu, X., Hang, J., Yao, D., \& Shi, G. (2016). Do urban rail transit facilities affect housing prices? Evidence from China. Sustainability, 8(4), 380. https://doi.org/10.3390/su8040380

\section{About the Author}

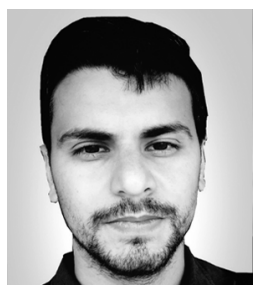

Rohit Sharma has over six years' experience as a practitioner and researcher in the fields of transportation, cities, economics and public policy. He has worked in India and Australia with consultants, universities and government organizations. His skills are in developing integrated transport strategy, sustainable mobility, town planning, PPPs, economics of infrastructure, econometrics and new governance systems for enabling alternative financing and decarbonisation in cities. 